\title{
New and Enduring Themes in Development Economics
}




\section{Statistical Science and Interdisciplinary Research}

\section{Series Editor: Sankar K. Pal (Indian Statistical Institute)}

\section{Description:}

In conjunction with the Platinum Jubilee celebrations of the Indian Statistical Institute, a series of books will be produced to cover various topics, such as Statistics and Mathematics, Computer Science, Machine Intelligence, Econometrics, other Physical Sciences, and Social and Natural Sciences. This series of edited volumes in the mentioned disciplines culminate mostly out of significant events conferences, workshops and lectures - held at the ten branches and centers of ISI to commemorate the long history of the institute.

Vol. 1 Mathematical Programming and Game Theory for Decision Making edited by S. K. Neogy, R. B. Bapat, A. K. Das \& T. Parthasarathy (Indian Statistical Institute, India)

Vol. 2 Advances in Intelligent Information Processing:

Tools and Applications

edited by B. Chandra \& C. A. Murthy

(Indian Statistical Institute, India)

Vol. 3 Algorithms, Architectures and Information Systems Security edited by Bhargab B. Bhattacharya, Susmita Sur-Kolay, Subhas C. Nandy \& Aditya Bagchi (Indian Statistical Institute, India)

Vol. 4 Advances in Multivariate Statistical Methods edited by A. SenGupta (Indian Statistical Institute, India)

Vol. 5 New and Enduring Themes in Development Economics edited by B. Dutta, T. Ray \& E. Somanathan (Indian Statistical Institute, India)

Vol. 6 Modeling, Computation and Optimization edited by S. K. Neogy, A. K. Das and R. B. Bapat (Indian Statistical Institute, India) 


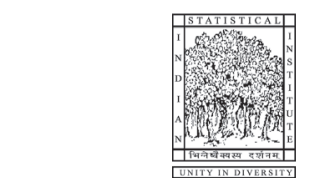

Platinum Jubilee Series

Statistical Science and Interdisciplinary Research - Vol. 5

\title{
New and Enduring Themes in \\ Development Economics
}

\author{
Editors \\ Bhaskar Dutta \\ Indian Statistical Institute, India \& Warwick University, UK \\ Tridip Ray \\ Indian Statistical Institute, India \\ E. Somanathan \\ Indian Statistical Institute, India
}

Series Editor: Sankar K. Pal 


\section{Published by}

World Scientific Publishing Co. Pte. Ltd.

5 Toh Tuck Link, Singapore 596224

USA office: 27 Warren Street, Suite 401-402, Hackensack, NJ 07601

UK office: 57 Shelton Street, Covent Garden, London WC2H 9HE

\section{British Library Cataloguing-in-Publication Data}

A catalogue record for this book is available from the British Library.

\section{NEW AND ENDURING THEMES IN DEVELOPMENT ECONOMICS Statistical Science and Interdisciplinary Research - Vol. 5}

Copyright $\odot 2009$ by World Scientific Publishing Co. Pte. Ltd.

All rights reserved. This book, or parts thereof, may not be reproduced in any form or by any means, electronic or mechanical, including photocopying, recording or any information storage and retrieval system now known or to be invented, without written permission from the Publisher.

For photocopying of material in this volume, please pay a copying fee through the Copyright Clearance Center, Inc., 222 Rosewood Drive, Danvers, MA 01923, USA. In this case permission to photocopy is not required from the publisher.

ISBN-13 978-981-283-941-1

ISBN-10 981-283-941-0

Printed in Singapore. 


\section{FOREWORD}

The Indian Statistical Institute (ISI) was established on $17^{\text {th }}$ December, 1931 by a great visionary Prof. Prasanta Chandra Mahalanobis to promote research in the theory and applications of statistics as a new scientific discipline in India. In 1959, Pandit Jawaharlal Nehru, the then Prime Minister of India introduced the ISI Act in the parliament and designated it as an Institution of National Importance because of its remarkable achievements in statistical work as well as its contribution to economic planning.

Today, the Indian Statistical Institute occupies a prestigious position in the academic firmament. It has been a haven for bright and talented academics working in a number of disciplines. Its research faculty has done India proud in the arenas of Statistics, Mathematics, Economics, Computer Science, among others. Over seventy five years, it has grown into a massive banyan tree, like the institute emblem. The Institute now serves the nation as a unified and monolithic organization from different places, namely Kolkata, the Head Quarters, Delhi, Bangalore and Chennai, three centers, a network of five SQC-OR Units located at Mumbai, Pune, Baroda, Hyderabad and Coimbatore, and a branch (field station) at Giridih.

The platinum jubilee celebrations of ISI have been launched by Honorable Prime Minister Prof. Manmohan Singh on December 24, 2006, and the Govt. of India has declared $29^{\text {th }}$ June as the "Statistics Day" to commemorate the birthday of Prof. Mahalanobis nationally.

Prof. Mahalanobis, was a great believer in interdisciplinary research, because he thought that this will promote the development of not only Statistics, but also the other natural and social sciences. To promote interdisciplinary research, major strides were made in the areas of computer science, statistical quality control, economics, biological and social sciences, physical and earth sciences.

The Institute's motto of 'unity in diversity' has been the guiding principle of all its activities since its inception. It highlights the unifying role of statistics in relation to various scientific activities.

In tune with this hallowed tradition, a comprehensive academic programme, involving Nobel Laureates, Fellows of the Royal Society, Abel prize winner and other dignitaries, has been implemented throughout the Platinum Jubilee year, 
highlighting the emerging areas of ongoing frontline research in its various scientific divisions, centers, and outlying units. It includes international and national-level seminars, symposia, conferences and workshops, as well as series of special lectures. As an outcome of these events, the Institute is bringing out a series of comprehensive volumes in different subjects under the title Statistical Science and Interdisciplinary Research, published by the World Scientific Press, Singapore.

The present volume titled "New and Enduring Themes in Development Economics" is the fifth one in the series. The volume consists of twenty chapters, written by eminent economists and experienced researchers from different parts of the world. The chapters deal with different aspects of development economics, e.g., inequality and well-being, interface between law and economics, political economy, labour economics, agriculture, macroeconomics and public finance. They represent a fine balance between theoretical and empirical studies addressing different challenging problems. Although some of the investigations are based on Indian data, the observations are of significance to other third world countries. I believe the state-of-the art studies presented in this book will be very useful to both researchers as well as policy makers.

Thanks to the contributors for their excellent research contributions, and to the volume editors Profs. Bhaskar Dutta, Tridip Ray and E. Somanathan for their sincere effort in bringing out the volume nicely in time. Initial design of the cover by Mr. Indranil Dutta is acknowledged. Sincere efforts by Prof. Dilip Saha and Dr. Barun Mukhopadhyay for editorial assistance are appreciated. Thanks are also due to World Scientific for their initiative in publishing the series and being a part of the Platinum Jubilee endeavor of the Institute.

August 2008

Kolkata

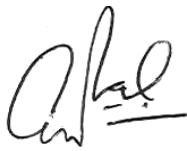

Sankar K. Pal Series Editor and Director 


\section{PREFACE}

This volume is a selection of papers by participants at the ISI Platinum Jubilee conference on Comparative Development held at the ISI, Delhi in December 2007. All papers have been peer reviewed.

The set of papers in the volume span an exciting set of both new and wellestablished topics in development economics, thus justifying the title of the volume. A brief discussion of a small selection of the papers indicates the range of topics covered.

Rethinking aspects of well-being and happiness is one of the exciting new areas in development economics. John Helliwell, Haifang Huang and Anthony Harris examine the determinants of life satisfaction as measured by surveys of individuals. They show that income, measures of deprivation, and other personal and national circumstances are together good predictors of life satisfaction. In another paper in the section on inequality and wellbeing, T. Lakshmanaswami explores the intergenerational links in the transmission of economic advantage under assortative marital sorting.

The interface between law and economics is another exciting area of research, at least partly because it is of great topical interest. For instance, public outrage arising from witness subversion and perversion of justice has reversed verdicts on appeal in several recent cases in India. Brendan O'Flaherty and Rajiv Sethi examine the role of public outrage in delivering justice when judicial effectiveness is poor.

Some of the papers are in political economy, another very popular area of research. Abhirup Sarkar conducts a theoretical analysis of why in developing countries like India, political parties often call general strikes that are unlike strikes in factories - the former are often held as general protests without any specific economic goals. Suman Majumdar and Sharun Mukand examine the role of policy interventions in bringing about institutional change in a framework where existing political incentives determine a country's economic institutions.

T.N. Srinivasan's paper goes back to an issue which has been hotly debated by development economists in recent times. What is the cause of the agrarian crisis in India in since the 1990s? Has it been caused by the opening up of the Indian economy to external competition? Or is it the result of India 
implementing the Agreement on Agriculture of the Uruguay Round of Multilateral Trade Negotiations? Or has it been caused by the decline of public investment in agriculture in response to rising fiscal deficits? Srinivasan argues that the principal reason for the agrarian crisis has been the faulty government policies prior to 1990 - in particular a development policy which placed far to much emphasis on import substituting industrialization with emphasis on heavy industry and insulation from the world economy.

The volume also includes several papers on what can be broadly categorized as Labour economics. In a particularly interesting paper, Kaushik Basu, Gary Fields and Shub Dasgupta construct a theoretical model to analyze the effects of labour legislation which make it costly for firms to dismiss or retrench workers. They show that such laws can cause wages and employment to rise or fall, depending on the parametric conditions prevailing in the market. They then isolate conditions under which an anti-retrenchment law raises wages and employment.

Other papers in the volume discuss several contemporary issues in areas such as macroeconomics and public finance. Several of the empirical papers are based on Indian data. But, of course, the lessons learnt from them are relevant for all developing countries.

We are grateful to all those who helped make the conference and this volume a success, particularly our doctoral students Ashokankur Datta, Mridu Prabal Goswami, Namrata Gulati, Ridhima Gupta, Dushyant Kumar, Debdatta Saha, and Soumendu Sarkar who helped with the editing.

\author{
Bhaskar Dutta \\ Tridip Ray \\ E.Somanathan
}




\title{
CONTENTS
}

\author{
Foreword \\ Preface
}

\section{Inequality and Wellbeing}

International Differences in the Determinants of Life Satisfaction

John F. Helliwell, Haifang Huang and Anthony Harris

Unequal Chances: The Intergenerational Transmission of Economic

Advantage under Marital Sorting

T. Lakshmanasamy

Addressing Equity Issues in Watershed Development Projects in

Bhil Adivasi Areas of Western Madhya Pradesh

Rahul Banerjee

\section{Politics, Law and Economics}

A Theory of the Corrupt Keynesian

Toke Aidt and Jayasri Dutta

On Effecting Institutional Change

Sumon Majumdar and Sharun Mukand

On the Political Economy of General Strikes

Abhirup Sarkar

Public Outrage and Criminal Justice: Lessons from the Jessica Lal Case Brendan O'Flaherty and Rajiv Sethi 
Lobbying for Trade Regime and Tariff Settings

Katsuzo Yamamoto

\section{Labour}

Labor Retrenchment Laws and Their Effect on Wages and

Employment: A Theoretical Investigation

Kaushik Basu, Gary S. Fields and Shub Debgupta

Work Migration in and Investment in Origin Communities

Ghazala Mansuri

Labour Market Reform and Poverty: The Role of Informal Sector

Sugata Marjit, Saibal Kar and Dibyendu Sundar Maiti

Measuring Harm due to Child Work and Child Labour: Patterns and

Determinants for India

Diganta Mukherjee and Saswati Das

\section{Agriculture}

Development Strategy: The State and Agriculture Since Independence T.N. Srinivasan

Land-Use Changes and Agricultural Growth in India, Pakistan, and Bangladesh, 1901-2004

Takashi Kurosaki

\section{Macro and Public Finance}

The Natural Interest Rate in Emerging Markets

Ashima Goyal

Intergovernmental Transfer Rules, State Fiscal Policy and Performance in India 
Tax Evasion and Administrative Costs

Rohit Prasad

Inequality, Public Investment and Deficits in India

Errol D'Souza

\section{Environment}

Climate Change and the Kyoto Protocol

Parkash Chander

\section{Finance}

Recent Trends in Microfinance Institutions: Some Theoretical Implications

Suman Ghosh and Eric Van Tassel 